\title{
DETERMINAN RENDAHNYA PARTISIPASI IBU HAMIL DALAM MENGIKUTI KELAS IBU HAMIL DI WILAYAH KERJA PUSKESMAS SUNGAI SALAK
}

\section{LOW DETERMINANTS OF PREGNANT MOTHER PARTICIPATION IN FOLLOWING PREGNANT WOMEN CLASSES IN THE WORKING AREA SALAK RIVER HEALTH CENTER}

\author{
Oleh: \\ Sherly Vermita Warlenda ${ }^{1}$, Nila Puspita Sari ${ }^{2}$, Endang Faridawati ${ }^{3}$, Arief Wahyudi ${ }^{4}$ \\ 1,2,3,4Program Studi S1 Kesehatan Masyarakat, STIKes Hang Tuah \\ Sherlyvermita130988@gmail.com
}

\begin{abstract}
Class of pregnant women is one of the strategies in an effort to improve the welfare of pregnant women and babies who support the decline in maternal mortality. Participation of Pregnant Women in the Classroom of Pregnant Women in the working area of Sungai Salak Health Center is only $38.80 \%$ and maternal / maternal mortality is still found in 2016 and 2017. The purpose of this study is to obtain indepth information about the determinants of the low participation of pregnant women in pregnant women. in the Sungai Salak Health Center Work Area. The research method used was descriptive qualitative through in-depth interviews. Determination of research subjects was carried out by purposive sampling and fulfilling the principle of conformity and adequacy, namely 2 health workers (midwives) as key informants, 6 pregnant women who did not attend pregnant mothers regularly as the main informants and 5 family / husbands as supporting informants. The results showed that the determinants of the low participation of pregnant women in taking classes in pregnant women due to lack of knowledge of pregnant women and lack of family / husband support. The positive attitude of mothers and the support of health workers for the class of pregnant women did not determine the participation of mothers in taking classes in pregnant women. It is expected that Sungai Salak Community Health Center can increase efforts to deliver information about classes of pregnant women not only through counseling, but also through the use of better information media so that people can receive informationwell.
\end{abstract}

Keywords : Class of pregnant women, mother's knowledge

\begin{abstract}
ABSTRAK
Kelas ibu hamil adalah salah satu strategi dalam upaya meningkatkan kesejahteraan ibuhamil dan bayi yang turut mendukung penurunan Angka Kematian Ibu. Keikutsertaan Ibu Hamil dalam Kelas Ibu Hamil di wilayah kerja Puskesmas Sungai Salak hanya 38,80 \% dan masih ditemui kematian ibu hamil/bersalinpada tahun 2016 dan 2017. Tujuan penelitian ini adalah diperolehnya informasi mendalam tentang determinan rendahnya partisipasi ibu hamil dalam mengikuti kelas ibu hamil di Wilayah Kerja Puskesmas Sungai Salak. Metode Penelitian yang digunakan adalah kualitatif deskriptif melalui wawancara mendalam. Penentuan subyek penelitian dilakukan secara purposive sampling dan memenuhi prinsip keseuaian dan kecukupan, yaitu 2 orang tenaga kesehatan (Bidan) sebagai informan kunci, 6 orang ibuhamil yang tidak mengikuti kelas ibuhamil secara rutin sebagai informan utama dan 5orang keluarga / suami sebagai informan pendukung. Hasil penelitian didapatkan bahwa determinan rendahnya partisipasi ibu hamil dalam mengikuti kelas ibu hamil karena kurangnya pengetahuan ibu hamil dan kurangnya dukungan keluarga / suami. Sikap positif ibu dan dukungan tenaga kesehatan terhadap kelas ibu hamil tidak menentukan partisipasi ibu dalam mengikuti kelas ibu hamil. Diharapkan kepada Puskesmas Sungai Salak agar dapat meningkatkan upaya penyampaian informasi tentang kelas ibu hamil tidak hanya melalui penyuluhan, tetapi dapat melalui penggunaanmedia informasi yang lebih baik agar masyarakat dapat menerima informasi dengan baik.
\end{abstract}

Kata Kunci :Kelas ibu hamil, pengetahuan ibu 


\section{PENDAHULUAN}

Ibu hamil adalah wanita yang sedang dalam berbadan dua ataupun wanita yang sedang mengandung janin di dalam rahimnya. (Kamus Besar Bahasalndonesia). Upaya peningkatan derajat kesehatan terutama pada kelompok masyarakat yang rentan kesehatan seperti ibu hamil, ibu bersalin dan nifas juga bayi pada masa perinatal. Kesehatan ibu hamil mulai dari persiapan kehamilan sampai menjelang proses persalinan merupakan dukungan bagi kehamilan yang sehat dan berkualitas menunjang upaya peningkatan derajat kesehatan(Kemenkes RI, 2013).

Direktur Bina Kesehatan lbu Kementerian Kesehatan RI mengatakan bahwa ketidakberdayaan seorang ibu dalam mengambil keputusan untuk mendapatkan pelayanan kesehatan saat terjadi masalah pada kehamilan atau bayinya menjadi salah satu penyebab tingginya AKI dan AKB. Ini dikarenakan antara lain oleh rendahnya pengetahuan ibudalam perawatan kesehatan dirinya jugatentang mengenal tanda-tanda bahaya obstetri dan neonatal, sehingga menjadi tertunda atau terhalangnya dalam mengambil keputusan (Kemenkes RI, 2013).

Menurut Laporan World Bank tahun 2017, di Indonesia setiap harinya ditemui 4 orang lbu meninggal karena melahirkan artinya ada seorang ibu meninggal setiap 6 jam. Angka ini menjadikan Indonesia sebagai negara dengan angka kematian ibu tertinggi kedua di Asia Tenggara setelah Laos. Sedangkan menurut Survei Demografi Kesehatan Indonesia tahun 2012, terdapat 19 bayi baru lahir(neonatal) meninggal ditiap 1.000 kelahiran dan sebanyak 32 bayi meninggal di tiap 1000 kelahiran hidup di Indonesia (Kumparan SAINS, 2018).

Pada tahun 2015 kematian ibu di Indonesia mencapai 305 per 100.000 kelahiran hidup. AKI tersebut belum mencapai target Millenium Development Goals (MDGs) yakni sebesar 102 kematian per 100.000 kelahiran hidup atau mengurangi $3 / 4$ jumlah kematian ibu. Upaya penurunan AKI ini masih dijadikan sebagai target Sustainable Development Goals (SDGs) yaitu hingga di bawah 70 per 100.000 kelahiran hidup pada tahun 2030 (Dirjen Bina
Gizi KIA, 2015). Pada tahun 2016 penyebab kematian ibudi Indonesia banyak disebabkan oleh perdarahan yaitu sebanyak $32 \%$ kemudian karena Hipertensi dalam kehamilan yang menyebabkan ibu hamil kejang dan keracunan kehamilan sehingga ibu meninggal sebanyak $26 \%$ dan selebihnya karena infeksi (sepsis) dan sebab lainnya (Kementerian Kesehatan RI, 2016). Di Provinsi Riau, AKI sejak tahun 2013 hingga sekarang mengalami turun naik dan masih tergolong tinggi, dimana pada tahun 2017 AKI mencapai 119 orang dengan penyebab terbesar adalah perdarahan sebanyak $45 \%$. Sedangkan di Kabupaten Indragiri Hilir sendiri tahun $2017 \quad$ AKI sebanyak 9 orang dengan penyebab terbesarnya juga adalah karena perdarahan yaitu sebanyak 8 orang (Dinas Kesehatan Inhil, 2017). Begitu juga di wilayah kerja Puskesmas Sungai Salak kematian Ibu pada tahun 2016 sebanyak 3 orang dan pada tahun 2017 adalah sebanyak 1 orang dengan penyebab kematian adalah karena perdarahan serta hipertensi dalam kehamilan / eklamsia (Puskesmas Sungai Salak, 2017).

Penyebab kematian ibu diatas sebenarmya dapat dicegah dengan pemeliharaan kesehatan ibuhamil yang berkualitas dimulai dari masa kehamilan hingga setelah persalinan/nifas. Salah satu upaya untuk meningkatkan kesehatan ibu menurut UU No 36 tahun 2009 yang bertujuan untuk menjaga kesehatan ibu dan anak serta mengurangi angka kematian ibu adalah dengan meningkatkan pelayanan kebidanan yang baik dan penyebaran buku KIA melalui program kelas ibuhamil yang terdapat dalam rencana strategi pemerintah (Kemenkes RI, 2013).

Pemberian informasi kesehatan ibu dan anak pada umumnya dilakukan pada saat ibu melakukan pemeriksaan kehamilan melalui konsultasi perorangan maupun saat diadakannya posyandu. Meski hal ini sangat bermanfaat untuk menangani kasus-kasus yang ditemui pada masa kehamilan, namun dirasakan pemerintah masih banyak kelemahan-kelemahan. Karena itu kelas ibu hamil menjadi kegiatan yang terencana yang membahas materi Buku KIA dalam bentuk kelompok diskusi dan tukar pendapat yang diikuti oleh ibu-ibu hamil minimal 4 kali 
pertemuan selama hamil, suami atau keluarga minimal ikut 1 kali pertemuan, serta kader (Kemenkes RI, 2013).

Kelas Ibu Hamil merupakan sarana bagi ibu hamil untuk belajar bersama tentang kesehatan bagi ibu hamil, dalam bentuk tatap muka dalam kelompok yang bertujuan untuk meningkatkan pengetahuan dan keterampilan ibu-ibu mengenai kehamilan, persalinan, nifas, KB pasca persalinan, pencegahan komplikasi, perawatan bayi baru lahir dan aktifitas fisik/senam ibu hamil dengan jumlah peserta tiap kelompok maksimal 10 orang (Kemenkes RI, 2013).

Tujuan dari kelas ibu hamil secara umum adalah meningkatkan pengetahuan, merubah sikap dan perilaku agar memahami tentang pemeriksaan kehamilan agar ibu dan janin sehat,persalinan aman, nifas nyaman, ibu selamat, bayi sehat, pencegahan penyakit fisik dan jiwa, gangguan gizi dan komplikasi kehamilan, persalinan dannifas agar ibu dan bayi sehat, perawatan bayi baru lahir agar tumbuh kembangnya optimal serta aktifitas fisik ibu hamil. Dengan demikian hal ini secara tidak langsung akan menunjang dan berkontribusi dalam upaya penurunan Angka Kematian lbu (Kemenkes RI, 2013).

Jumlah ibu hamil Indonesia pada tahun 2017 adalah sebanyak 5.324.562 orang dan pada propinsi Riau sebanyak 165.625 orang, sedangkan di Kabupaten Indragiri Hilir sebanyak 15.841 jiwa. Pada tahun 2017 sebanyak 92,71\% Puskesmas se Indonesia telah melakukan kelas ibu hamil(Kementerian Kesehatan RI, 2014), namun di Kabupaten Indragiri Hilir ibu hamil yang terdata melakukan pemeriksaan pertama(K1) kehamilannya hanya sebanyak 13.219 orang $(83,44 \%)$ dengan jumlah ibuhamil yang mengikuti kelas ibu hamil sekitar 67,89\%, sedangkan keikutsertaan suami atau keluarga dalam kelas ibuhamil hanya mencapai $12,28 \%$ (Dinas Kesehatan Indragiri Hilir,2017).

Berdasarkan Data yang didapat dari Kesehatan Keluarga Dinas Kesehatan Kabupaten Indragiri Hilir tahun 2017 salah satu Puskesmas dengan jumlah peserta kelas ibu hamil terendah adalah Puskesmas Sungai Salak. (Dinas Kesehatan Indragiri Hilir,2017).
Pada tahun 2016 ibu hamil yang ikut dalam kelas ibu hamil hanya sebanyak 247 orang $(42,8 \%)$ dari 577 orang ibu hamil yang memeriksakan kehamilannya, sedangkan suami/keluarga yang ikut serta hanya 10 orang.(Dinas Kesehatan Indragiri Hilir, 2017).Pada tahun 2017 terjadi penurunan keikutsertaan ibuhamil dalam kelas ibu hamil, meski cakupan K 1 pada tahun 2017 di Puskesmas Sungai Salak mencapai 623 orang $(88,24 \%)$, namun tidak semua ibu hamil tersebut mengikuti kelas ibu hamil(Dinas Kesehatan Indragiri Hilir, 2017).

Keikutsertaan ibuhamil dalam kelas ibu hamil di Puskesmas Sungai Salak hanya 239 orang $(38,8 \%)$ artinya sebanyak $61,2 \%$ ibu hamil tidak mengikuti kelas ibu hamil, sedangkan keikutsertaan keluarga/suami hanya sebanyak 5 orang $(0.8 \%)$. Ini menerangkan bahwa cakupan keikutsertaan Ibu hamil dan keluarga dalam kelas ibu hamil di Puskesmas Sungai Salak adalah yang terendah dibandingkan dengan 26 Puskesmas lainnya yang berada di Kabupaten Indragiri Hilir.

Survei awal yang telah dilakukan terhadap 10 orang ibu hamil di wilayah kerja Puskesmas Sungai Salak, didapatkan sebanyak 9 orang ibutidak pernah mengikuti kelas ibu hamil dikarenakan belum mengerti tujuan kelas ibu hamil juga tidak adanya dukungan keluarga serta kesibukan suami dan 1 orang pernah mengikuti hanya 1 kali. Dari wawancara awal terhadap Bidan di Puskesmas Sungai Salak, Bidan mengatakan bahwa masyarakat tidak aktif mengikuti kelas ibu hamil dan kehadiran ibu hamil serta keluarga juga sangat rendah hanya 5-6 orang saja setiap kelas yang diadakan, hal ini dikarenakan kurangnya dukungan dari keluarga / suami. Ada banyak hal yang menyebabkan masyarakat berperilaku / berupaya dalam meningkatkan kesehatannya seperti mengikuti kelas ibu hamil, antara lain karena faktor pengetahuan, kepercayaan, tradisi, dukunga keluarga, sarana dan prasarana, informasi, jarak/keterjangkauan tempat pelayanan, informasi dan lain-lain (Notoatmodjo, 2012).

Hal diatas sejalan dengan hasil penelitian yang dilakukan oleh Yuliantika 
(2016) menunjukkan bahwa faktor yang berhubungan dengan partisipasi ibu hamil untuk mengikuti kelas ibu hamil adalah pengetahuan, sikap serta dukungan dari keluarga maupun dukungan petugas kesehatan serta pemerintah desa (Yuliantika, 2016). Rendahnya keikutsertaan dalam kelas ibu hamil ini juga dikemukakan oleh Ida Baroroh dan kawan-kawan, dalam penelitianmya bahwa ada hubungan antara pengetahuan dengan keikutsertaan ibu hamil dalam kelas ibu hamil (Baroroh et al., 2017).

Berdasarkan data tersebut diatas, maka peneliti tertarik untuk melakukan penelitian tentang "Determinan Rendahnya Partisipasi lbu HamilDalam Mengikuti Kelas Ibu Hamil di Wilayah Kerja Puskesmas Sungai Salak Tahun 2018"

\section{METODE}

Penelitian ini yaitu menggunakan metode penelitian kualitatif deskriptif yaitu jenis penelitian yang tujuannya menyajikan gambaran lengkap mengenai suatu fenomena atau kenyataan sosial. Waktu penelitian dilaksanakan pada bulan Oktober 2018 hingga bulan Desember 2018. Informan Kunci dalam penelitian ini adalah petugas kesehatan/Bidan, serta ibu hamil yang tidakmengikuti.

\section{HASIL PENELITIAN}

\section{Pengetahuan Ibu}

Dari hasil wawancara mendalam mengenai

pengetahuan ibutentang kelas ibu hamil diketahui bahwa pengetahuan informan tentang kelas ibuhamil masih kurang, seperti yang ungkapan dibawah ini: kelas ibu hamil secara rutin sebagai informan utama dan keluarga atau suami sebagai informan pendukung sebanyak 13 orang. Instrumen Penelitian adalah pedoman wawancara mendalam dengan alat bantu seperti recoder, kamera, buku catatan dan alat tulis serta observasi. Kemudian analisis data dilakukan dengan cara reduksi data, penyajian data dan penarikan kesimpulan dan vertifikasi.

"Kelas ibu hamil..tempat perkumpulan ibu hamil yang diadakan bulan sekali.itu saja..."(IU 2)
"Posyandu, periksa kehamilan..kandungan.."(IU 3)

"Tentang anu leeh. Apalagi leeh?(IU 5)

Hasil wawancara terhadap 6 (enam) orang informan utama menyatakan bahwa pengetahuan ibu tentang kelas ibu hamil sebagai berikut : tempat perkumpulan ibu hamil yang diadakan satu bulan sekali, yang mempelajari segala hal mulai dari kehamilan sampai kelahiran dan caramenyusui. Selain itu informan juga menyatakan bahwa kelas ibu hamil sebagai tempat pemeriksaan kehamilan dan sebagian besar informan tidak dapat menjelaskan dengan benar apa yang dimaksud dengan kelas ibu hamil sesuai dengan pernyataan dibawah ini :

“pemeriksaaan..ya itu aja”(IU 1)

"itu saja...'(IU 2)

"senam-senam tu tak ada."(IU 3)

Pernyataan diatas juga didukung oleh informan pendukung dan informan kunci yaitu: "Pos yandu kehamilan.." (IP 2)

"Ee...yang jelas tentang.. informasi perkembangan ibu hamil..dari bu bidan.tentang ibu hamil..pembelajaran untuk ibu- ibu hamil..'(IP 3)

"Eee..kalau dari yang datang..kalau sudah kehamilan anak yang kedua.....ketiga. pengetahuanny asudah banyak..yang..memang pengetahuannya lebih luas,...tapi kalau dilihat dari ini..masih kurang bu..'(IK2)

Berdasarkan hasil wawancara terhadap semua informan diatas, maka dapat disimpulkan bahwa pengetahuan sebagian besar ibu hamil tentang kelas ibuhamil masih kurang, begitu juga dengan pengetahuan keluarga/suami sebagai informan pendukung. Informan hanyamengetahui bahwa kelas ibu hamil sebagai tempat perkumpulan ibu hamil namun tidak dapat menjelaskan dengan benar maksud dari kelas ibu hamiltersebut.

Dari hasil wawancara kepada ibu hamil dari mana mereka memperoleh/mendengar tentang kelas ibu hamil sepertiungkapan di bawah ini:

"Dari Bu Bidan "(IU1)

"kemaren pernah ke Puskesmas"(IU 2)

"Semenjak ikut posyandu.."(IU 3 )

"Dari orang sekitar..dari saudara, teman..orang-orang terdekat..." (IU 4) 
"Bebaru ini aja tau kelas ibu hamil..dari buku.dari orang yang mau ikut kelas ibu hamil.."( IU 5)

"Dari ibu-ibu lah..dari Bidan..(IU 6)

Dari hasil wawancara diatas Infoman utama mengatakan bahwa mereka mendapatkan informasi tentang kelas ibuhamil dari Bidan, di Posyandu, membaca buku. Selain itu Informan utama juga menyatakan bahwa informasi didapat dari kader, ibu-ibu hamil, namun lebih banyak dari Bidan seperti ungkapan dibawah ini:

"Hanya dari Bu Bidan"(IU 1) "Diterangkan oleh

Bu Bidan..."(IU2)

Pernyataan ini dudukung juga oleh pernyataan informan pendukung di bawah ini : "Yang jelas informasi dari bu

bidannya..tentang ibuhamil...pembelajaran untuk

ibu-ibu hamil"(IP 3)

Berdasarkan hasil wawancara diatas, 6 (enam) orang informan utama mengatakan bahwa mereka memperoleh informasi tentang kelas ibu hamil kebanyakan dari Bidan, kader dan ibu-ibu hamil. Sedangkan informan pendukung menyatakan memperoleh informasi tentang kelas ibu hamil dari istri dan dari puskesmas juga dari Bidan. Maka disimpulkanbahwa informasi tentangkelas ibu hamil mayoritas diperoleh dari tenaga kesehatan dankader.

Hasil wawancara mendalam terhadap 6 (enam) orang informanutama tersebut kegiatan yang dilaksanakan dalam kelas ibuhamil seperti ungkapan di bawah ini:

"Cek kandungan...pemeriksaan..eee.. apa ya" (IU 4)

"Oooh..kursus ibu hamil..dapat

pengetahuan..senam ibuhamil ...macam

macam,bu..penyuluhan tentang ibu

hamil.tentang cara melahirkan.."(IU 5)

"Pertama kegiatannya senam.."(IU 6)

Berdasarkan hasil wawancara mendalam terhadap Informan Utama, diperoleh informasi tentang kegiatan yang dilaksanakan di dalam kelas ibu hamil sebagi berikut : periksa kehamilan, penyuluhan tentang ibu hamil dansenam.

Selain itu beberapa informan utama juga menyatakan kalau mereka kurang memahami kegiatan apa aja yang dilakukan dikelas ibu hamil, seperti ungkapan dibawah ini:

Pernyataan diatas didukung oleh peryataan Informan Pendukung sebagai berikut:

"Ee...yang jelas tentang informasi perkembangan ibu hamil dari bu bidan..tentang ibu hamil.. pembelajaran untuk ibu- ibu hamil..." (IP 3)

"Hee..tak ngerti,bu..tak pernah mendengar tentang kelas ibu hamil..ya..dia periksa..."(IP 4) "Itu..berkumpul, diundang sama ibu-ibu bidan..terus dinasehati makanannya yang bergizi..disuruh senam..supaya sehat, tiap bulannya diundang..."(IP5)

Berdasarkan hasil wawancara mendalam diatas, diperoleh sebagian informan menyatakan kegiatan kelas ibu hamil yang dilaksanakan adalah penyuluhan dan penjelasan tentang kehamilan, persalinan, perawatan bayi baru lahir serta senam ibu hamil. Namun sebagian lagi hanya mengetahui kelas ibu hamil sebagai tempat periksa kehamilan.Sedangkan informan pendukung mayoritas kurang memahami apa kegiatan yang ada dalam kelas ibu hamil tersebut. Maka dapat disimpulkan bahwa informan kurang mengetahui apa saja kegiatan yang dilaksanakan didalam kelas ibuhamil.

Dari hasil wawancara pada informan utama, maka diperoleh informasi seperti ungkapan sebagai berikut :

"kita kan datang 1 bulan sekali...pertama kali kita datang..nanti pas tu..ada salah satu Bidan menerangkan tentang kehamilan..misalnya minggu ini kelas ibu hamil tentang kehamilan.."(IU 1)

"Kalau kita sering rutin mengikuti jadi kita tau kayakmana...nantinya apa saja persiapan untuk kelahiran nanti"(IU 2)

Dari hasil wawancara diatas diperoleh informasi bahwa informan utama mengetahui manfaat kelas ibu hamil untuk mengetahui kesehatan ibu dan anak. Selain pernyataan diatas informan utama juga menyatakan bahwa manfaat kelas ibu hamil adalah agar ibu hamil paham tentang kehamilan, berbagi pengalaman sesama ibu hamil. namun sebagian besar ibu hamil tidak dapat menjelaskan dengan benar seperti ungkapan 
berikut ini:

"Yaa..manfaatnya untuk pemahaman pada ibu hamil tentang kehamilan.walaupun kita melahirkan bukan sekali 2 kali..kadang kan kita lupa.(IU 1)

"Selain itu,,ee..bisa berbagi sesama ibu hamil misalnya tentang kehamilannya..cerita bagi..berbagi pengalamanlah..kayak gitu, bu.."(IU2)

"Sangat berguna untuk kesehatan bayi..senam agar sehat..periksa periksa kan,,.," (IU6)

Pernyataan tersebut didukung oleh pernyataan informan pendukung yaitu : Berdasarkan hasil wawancara diatas, dapat disimpulkan bahwa pengetahuan informan tentang kelas ibuhamil masih kurang, mereka juga belum memahami apa saja manfaat dari kelas ibu hamil denganbenar.

\section{Sikap Ibu}

Dari hasil wawancara mendalam terhadap informan, diperoleh informasi seperti ungkapan sebagai berikut :

" Bagus..Yaa..kita mendapat perawatan..kita dapat periksa."(IU 1)

"Sangat bermanfaatlah kan..itu adi kan..kita

bisa mengetahui perkembangan ibu dan janin.."(IU 4)

"Bagus bu ai...ada kelas ibu hamil tu..'(IU 5)

"Sangat bermanfaat bagi ibu hamil dan berguna bagi kesehatan kandungan"(IU6)

Berdasarkan hasil wawancara terhadap informan utama, diperoleh informasi bahwa pendapat mereka tentang kelas ibu hamil sebagai berikut : sangat bermanfaat karena dapat mengetahui tentang perkembangan kehamilan dan kesehatankandungan. Pernyataan diatas didukung oleh pernyataan dari informan pendukung yang menyatakan bahwa kelas ibu hamil penting diadakan seperti ungkapan dibawah ini :

"Pentinglah,bu..bagi ibu-ibu hamil ni kan terbantulahkan...periksa setiap bulan..membantu ibu hamil ni kayak manakayak mana' (IP 1)

"Pentinglah..untuk kesehatan ibu hamil.supaya melahirkan nanti yang enak..untuk kesehatan bayinya..untuk kesehatan ibunya"(IP5)

Berdasarkan hasil wawancara diatas, 6(enam) orang informan utama dan informan pendukung menyatakan bahwa dengan adanya kelas ibuhamil sangat bagus, mereka mendapat informasi tentang kehamilan, persalinan, pengalaman dari ibu hamil lainnya dan penting untuk kesehatan ibu danjanin.

Dari hasil wawancara mendalam, diperoleh informasi tentang penyebab ibu tidak rutin mengikuti kelas ibu hamil seperti ungkapan sebagaiberikut :

"Karena kerja.."(IU 4)

"Karena tukang antar dedak jua..suami ke kebun.."(IU 5)

"Kendaraan tidak ada...anak tidak ada tempat menitip"(IU 6)

Hasil wawancara diatas, diperoleh informasi alasan ibu hamil tidak mengkuti kelas ibu hamil secara rutin sebagai berikut : kesibukan kerja, sakit dan karena suami sedang bekerja. Selain itu, beberapa informan mengutarakan bahwa saat pelaksanaan kelas ibu hamil berbenturan dengan pekerjaan seperti ungkapan dibawah ini :

"Jadwalnya bentrok dengan jadwal kerja,kerjanya kan di PT,bu.(IU4)

Pernyataan diatas didukung oleh pernyataan dari informan

pendukungdan informankuncisebagai berikut :

"Supaya dia mau ikut..kalau saya tidak bias

antar..minta antar sama yang lain..karena

saya kerja, bu..libur cuma hari minggu.."(IP5)

"Kalau dari sikap sepertinya mereka ini,bu..ikut..mau..ikut..sikapnya

bagus..baik..mereka datang (IK2)

Berdasarkan hasil wawancara tersebut, informan menyatakan bahwaalasan mereka tidak rutin mengikuti kelas ibuhamil adalah karena sakit, kesibukan (pekerjaan di rumah), tidak ada tempat menitip anakserta tidak ada yang menemani/mengantar ibu (pekerjaan suami).

Dapat disimpulkan bahwa sikap ibuhamil maupun keluarga terhadap kelas ibu hamil adalah baik/positif, namun mereka belum mengaplikasikan dalam praktiknya. Alasannya karena kesibukan pekerjaan rumah serta kesibukansuami.

\section{Dukungan keluarga/suami}

Dari hasil wawancara mendalam, diperoleh informasi tentang dukungan 
keluarga/suami hanya sebatas memberikan saran seperti pada ungkapan di bawah berikut :

"Suami tidak pernah mengikuti kelas ibu hamil..pertama kali tidak menyarankan..katanya tiap bulan pergi..tak usahlah..tapi yang kedua..demi untuk kesehatan ibu dan anak disarankan..suruh pergi,,tapi tidak bisa ikut kelas ibu hamil.. (IU1) "Sarannya...?kalau bagus..ada manfaatnya silahkan pergi." (IU 6)

Hal tersebut didukung oleh pernyataan dari informan pendukung sebagai berikut:

"Yaa..menyuruh ikut kelas ibu hamil aja,bu...tanggapannya..dia mau- mau aja ikut kelas ibu hamil...'(IP1) "Kayak mana baiknya ajalah. terserah aja."(IP 4)

"Supaya dia mau ikut..kalau saya tidak bisa antar..minta antar sama yang lain..karena saya kerja, bu..libur cuma hari minggu.."(IP6)

Berdasarkan hasil wawancara diatas, diperoleh informasi seluruh informan menyatakan bahwa bentuk dukungan suami terhadap ibu yaitu dengan menyarankan ibu untuk mengikuti kelas ibu hamil. Meski keluarga/suami telah menyarankan namun suami tidak dapat mendampingi karena alasan tidak dapat meninggalkan pekerjaan.

Dari wawancara mendalam terhadap informan mendalam maka diperoleh hasil seperti ungkapan sebagaiberikut :

"yaa..tanggapan..ya..gimana ya, kita hidup satu rumah satu keluarga namanya suami...harus ikut kata suami..kita pertimbangkan bagaimana..jadi dia mengizinkan..Suami sekarang mendukung tapi tidak pernah ikut kelas ibu hamil" (IU 1)

"Ya..saya pergi.. tapi suami tak ikut..karena kerja"(IU 6)

Dari hasil wawancara diatas, sebagian besar informan mengatakan mereka menanggapi saran dengan mengikuti saran suami untuk ikut kelas ibu hamil. Pernyataan diatas didukung oleh informasi dari informan pendukung seperti ungkapan dibawah ini :

"Ee...sarannya..yang jelasnya agar rutin ikut kelas ibu hamil, tanggapannya ...yang pertama karena ibu kerja,jadi terbentur dengan kerja."(IP3)

"Kayak mana baiknya ajalah...terserah aja..." (IP 4)
"Supaya dia mau ikut..kalau saya tidak bias antar..minta antar sama yang lain..karena saya kerja, bu..libur cuma hari minggu..' (IP5) Selain itu informan pendukung juga menyatakan bahwa keluarga/suami penting mendampingi ibu dan hadir dalam kelas ibuhamil seperti ungkapan berikut ini :

"Pentinglah, buentah apa yang mau dijelaskan..tapi tidak pernah ikut..ya..entah apa yang mau disampaikan ke suaminya..."(IP1)

"Menurut saya penting.bu..tapi saya kan kerja..kalau tak kerja dipotong gaji,bu..'(IP 5)

Berdasarkan hasil wawancara mendalam diatas, diperoleh informasi tentang tanggapan ibu setelah keluarga/suami memberi saran, maka ibu hamil menyatakan telah mengikuti saran dari keluarga/suami dan mengikuti kelas ibuhamil, keluarga juga menyatakan bahwa penting mendampingi ibuhamil suami harus tau perkembangan kehamilan. Walau demikian ibu tidak rutin mengikuti kelas ibu hamil dan pada observasi yang dilakukan peneliti terhadap pelaksanaan kegiatan kelas ibu hamil,suami tidak hadir disebabkan karena

kesibukan/pekerjaan suami. Maka dapat disimpulkan dalam hal ini dukungan keluarga/suami terhadap kelas ibu hamil masih kurang.

\section{Dukungan Tenaga Kesehatan}

Dari wawancara mendalam yang dilakukan terhadap informan utama, diperoleh hasil bahwa Bidan telah menyampaikan penjelasan tentang kelas ibu hamil dengan baik sesuai ungkapan sebagai berikut:

"Jelas..yaa.dia menerangkan dengan jelas tidak berbelit-belit gitukan..dapat kita pahami.."(IU 1)

"Periksa tiap bulan...periksa tensi "(IU 2)

Selain itu informan juga mengatakan bahwa tenaga kesehatan menjelaskan beberapa hal seperti perawatan kehamilan, masalah-masalah dalam kehamilan hingga melahirkan serta merawat bayi seta cara menyusui seperti ungkapan berikut ini:

"Mulai dari kehamilan sampai melahirkan, tanda-tanda kehamilan..ada juga tentang merawat anak..menyusui.." (IU1) "Tentang melahirkan..merawat bayi baru lahir.."(IU5) 
"Iyalah karena kan misalnya kalau kaki awak sakit..bengkak,,,dikasih tau bagaimana caranya supaya tidak bengkak lagi..olahraganya begini caranya ..supaya tidak bengkak lagi..'(IU6)

Pernyataan diatas didukung oleh penyataan Informan Pendukung seperti ungkapan berikut ini :

"Bagus..ngasih brosur..himbauan. '(IP3)

"Baik..memberitahukan. "(IP 4)

"Cukup bijaklah,bu.....kalau ............ kita datang ke puskesmas kadang ngadu...ditanggapilah '(IP5)

Berdasarkan hasil wawancara diatas, diperoleh informan menyatakan bahwa tenaga kesehatan telah menjelaskan dengan baik dan dapat dimengertioleh ibu hamil tentang kehamilan, cara mengatasi masalah dalam kehamilan, hingga persalinan serta perawatan bayi barulahir.

Dari hasil wawancara pada informan utama, diperoleh informasi bahwa tenaga kesehatan telah mengajak ibu- ibu hamil untuk mengikuti kelas ibu hamil dengan menjemput kerumah, memberikan undangan, seperti ungkapan sebagai berikut :

"Yaa..mengajaklah...ya..dia mengajak untuk ikut kelas ibu hamil'(IU1)

".Kalau..ada ngajak,,, ayo datang setiap tanggal 13..."(IU 2)

Selain itu, beberpa informan juga mengatakan bahwa Bidan selalu mengajak ikut dalam kegiatan kelas ibu hamil pada saat mereka melakukan pemeriksaan kehamilan.

"Iya..setiap periksa disuruh datang lagi"(IU1)

"Ya..mereka terus menganjurkan terus ikut kelas ibu hamil"(IU2)

Pernyataan ini didukung oleh pernyataan yang sama dari informan pendukung dan informan kunci sebagai berikut: "..Yang jelas mereka kan ada turun juga, puskesmas keliling..di posyandu.."(IP 3) "Ada lah, bu..."(IP 4)

Berdasarkan hasil wawancara yang dilakukan terhadap informan utamadiatas, maka diperoleh informasi bahwa Bidan telah mengajak ibu-ibu hamil untuk mengikuti kegiatan kelas ibu hamil dengan cara mengingatkan tanggal pelaksanaan, saat ibu hamil melakukan pemeriksaan kehamilan, dengan memberikan undangan serta menyampaikan melaluikader. Dari wawancara mendalam yang dilakukan maka diperoleh informasi seperti ungkapan berikut ini : "Kalau kujungan rumah...ee..soalnya mungkin karena saya baru disini,..kurang taulah..informasi dapat dari ikut Posyandu tu lah..dari Bidan.."(IU 3)

Hasil wawancara mendalam yang dilakukan terhadap informan utama dan informan pendukung mereka menyatakan sebagai berikut : Bidan telah melakukan kunjungan rumah, menyampaikan undangan kepada ibu hamil untuk mengikuti kelas ibu hamil serta menyampaikan beberapa informasi tentang kelas ibu hamil. Pernyataan diatas didukung juga oleh pernyataan dari informan pendukung dibawah ini : "Datanglah,bu..'(IP 1) "Pernah....waktu itu tidak ada dirumah...'(IP 4) "Ada,bu..kadang saya kurang tau,bu..karena saya kerja..ibu (istri) aja yang ada dirumah, bu"(IP5)

Berdasarkan hasil wawancara mendalam diatas dapat disimpulkan bahwa Bidan telah melakukan kunjungan rumah dan memberikan informasi tentang kelas ibu hamil. Dari wawancara mendalam yang dilakukan maka diperoleh informasi seperti ungkapan berikut ini

“..Setiap tanggal 13..'kalau hari libur bias maju atau mundur.. jadwal nya sudah ditentukan..."(IU 1 ) "Dari Bidan...sesuailah ,bu...' (IU5)

"Yaa..setiap bulan tu..ditetapkan oleh Bidan, dibagi undangan, kalau jadwal tu..kalau diinginkan..maunya hari minggu yaa..orangnya cuma sedikit yang pergi'(IU 6)

Hasil wawancara mendalam diperoleh informasi bahwa tanggal kegiatan kelas ibu hamil sudah ditetapkan oleh Bidan, mereka hanya menunggu informasi dari Bidan atau Kader setiap bulannya dan mereka menyepakati tanggal yang telah ditentukan.

Selain itu informan utama juga menjelaskan bahwa jadwal kegiatannya dapat disesuaikan jika bertepatan dengan hari libur, namun ada juga informan yang menginginkan kegiatannya diadakan dihari libur karena terbentur dengankerja.

Pernyataan ini didukung oleh pernyataan dari informan pendukung dan informan kunci sebagi berikut :

"Dibuat ibu bidan..kalau kami..ngikut 
aja..karena kami kerja juga..kami sepakat aja...'(IP 3)

Berdasarkan hasil wawancara diatas, informan menyatakan bahwa penjadwalan yang pertemuan kelas ibu hamil dibuat oleh Bidan namun telah disepakati,namun jika terkena hari libur maka kegiatan dilakukan sehari sebelum atau sesudahnya sesuai kesepakatan. Disamping itu ada juga keinginan informan kegiatan ini dilakukan di hari libur.

Peneliti berkesimpulan bahwa dukungan tenaga kesehatan terhadap kegiatan kelas ibu hamil ini telah diberikan dengan baik yang dinyatakan dengan memberikan himbauan, undangan,advokasi kepada pihak pengambil kebijakan danbekerjasama.

\section{PEMBAHASAN}

\section{Kecenderungan Pengetahuan Ibu tentang Kelas Ibu Hamil}

Dari hasil wawancara mendalam yang dilakukan terhadap 6 (enam) orang ibu hamil yang tidak mengikuti kelas ibu hamil secara rutindan didukung oleh informan pendukung dan informan kuncididapatkan informasi bahwa sebagian besar ibuhamil mengatakan bahwa kelas ibu hamil sebagai tempat perkumpulan ibu-ibu hamil, namun tidak dapat menjelaskan secara benartujuan, manfaat dan kegiatan yang dilaksanakan dari kelas ibu hamil tersebut.Sebagian informan mengatakan bahwa kelas ibu hamil tempat periksa kehamilan, hal ini menandakan bahwapengetahuan ibu hamil tentang arti kelas ibuhamil masih kurang. Hasil penelitian ini sejalan dengan penelitian Ranny Septiani (2013) dalam judul pengetahuan, sikap ibu hamil dan dukungan suami dengan keikutsertaan ibuhamil dalam kelas ibuhamil di Puskesmas Kota Metro Lampung yang mengatakan bahwa ibu hamil yang memiliki pengetahuan dan menyadari manfaat kelas ibu hamil akan secara aktif mengikuti kelas ibu hamil (Ranny,2013). Pengetahuan adalah hasil tahu seseorang terhadap obyek dengan pihak kelurahan desa serta kader. melalui penginderaan yang dimilikinya, sehingga tingkat pengetahuan seseorang menjadi berbeda beda. Tanpa pengetahuan seseorang tidak mempunyai dasar untuk mengambil keputusan dan menentukan tindakan terhadap masalah yang dihadapinya juga terhadap keputusan untuk berperilaku kesehatan. Keterbatasan pengetahuan akan menyulitkan seseorang untuk memahami pentingnya informasi seseorang memahami penting kemajuan informasi mengenai kesehatan dan perubahan sikap serta perilaku seseorang kearah yang menguntungkan (Notoatmodjo, 2012). Ada beberapa fakor yang mempengaruhi pengetahuan seseorang yaitu faktor internal : faktor dari dalam diri sendiri seperti intelegensia, minat dan kondisi fisik, sedangkan faktor eksternal : faktor yang datang dari luar dirinya seperti : keluarga, masyarakat dan sarana. Serta faktor pendekatan belajar : faktor upaya belajar misalnya strategi dan metode belajar (Achmadi,2013).

Berdasarkan hasil penelitian dan teori diatas, maka peneliti menganalisa bahwa pengetahuan ibu hamil cenderung kurang dan ini menjadi salah satu penyebab rendahnya partisipasi ibu hamil dalam mengikuti kelas ibu hamil. Terlihat dari jawaban ibu hamil hanya sebatas mengetahui kelas ibu hamil sebagai tempat perkumpulan ibu-ibu hamil, namun tidak dapat menjelaskan dengan benar apa tujuan serta manfaat dari kelas ibuhamil yang berarti ibu-ibu hamil tersebut memang belum memahami maksud dari kelas ibu hamil.Jadi menurut analisa peneliti berdasarkan informasi yang didapat dari informan utama, informan pendukung dan informan kunci, ibu-ibu hamil yang tidak rutin mengikuti kelas ibu hamil bukan saja disebabkan karena pengetahuannya yang masih kurang, namun juga didukung oleh pengetahuan dari keluarga/suami yang kurang sehingga tidak dapat mengaplikasikan dalam praktiknya.

\section{Kecenderungan Sikap Ibu terhadap Kelas Ibu Hamil}

Hasil wawancara mendalam dan observasi yang dilakukan terhadap 6 (enam) orang informan utama, diperoleh bahwa semua informan cenderung memiliki sikap yang positif terhadap adanya kelas ibu hamil ini. Sikap ibu dinyatakan dengan pendapat mereka bahwa kelas ibuhamil menguntungkan dan mereka merasa nyaman dengan adanya kelas ibu hamil 
ini karena dapat mengetahui perkembangan kesehatan kehamilannya, namun pada praktiknya informan tidak mewujudkannya dengan nyata dikarenakan pengetahuan informan yang masih kurang.Dalam hal ini tidak rutinnya ibu hamil mengikuti kelas ibu hamil bukan disebabkan karena faktor sikap negatif informan, namun karena faktor pekerjaan dan kesibukan ibu sebagai iburumah tangga yang mengasuh anak serta kesibukan suami.

Hasil penelitian ini tidak sejalan dengan penelitian Yuliantika (2016), bahwa sikap ibu hamil yang negatif akan memperbesar kemungkinan ibu hamil untuk tidak mengikuti kelas ibu hamil. Notoatmodjo (2012) menjelaskan bahwa suatu sikap belum pasti terwujud dalam suatu tindakan (overt behavior). Untuk mewujudkan sikapmenjadi suatu perbuatan yang nyata diperlukan faktor pendukung atau suatu kondisi yang memungkinkan seperti fasilitas dan faktor dukungan (Umar Fahmi Achmadi,2013).

Berdasarkan penelitian dan teori diatas, maka peneliti menganalisa bahwa sikap ibu hamil terhadap kelas ibu hamil adalah baik/positif. Dalam konteks kelas ibu hamil ini tidak selamanya sikap positif akan membuat seseorang melakukan praktiknya atau bertindak. Sikap ibu hamil yang positif ini juga perlu didukung oleh pengetahuan keluarga/suami yang baik agar dapat mengaplikasikannya dalam suatu tindakan pendukung yang positif, karena sikap dari keluarga/suami akan timbul jika pengetahuannya tentang kelas ibu hamil juga baik. Jadi menurut peneliti hasil penelitian ini tidak sesuai dengan hasil penelitian Yuliantika (2016) yang menyatakanbahwa sikap ibu hamil yang negatif akan memperbesar kemungkinan ibu hamil untuk tidak mengikuti kelas ibuhamil yang berarti sikap positif akan memperbesar kemungkinan ibu hamil mengikuti kelas ibu hamil. Hasil penelitian ini menyatakan bahwa keikutsertaan ibuhamil dalam mengikuti kelas ibu hamil tidak dipengaruhi oleh sikap positif atau sikap negatif ibu hamil, hal ini mungkin karena masih kurangnya pengetahuanibu juga keluarga/suami tentang pentingnya kelas ibu hamil.

\section{Kecenderungan Dukungan Keluarga/Suami terhadap Kelas IbuHamil}

Hasil wawancara mendalam dan observasi yang dilakukan terhadap informan utama juga informan pendukung, diketahui bahwa bentuk dukungan keluarga/suami hanya sebatas memberikan saran kepada ibu untukmengikuti kelas ibu hamil, namun suami tidak pernah mendampingi ibu / hadir dalam kegiatan tersebut. Dari wawancara yang dilakukan terhadap keluarga/suami juga diperoleh hasil bahwa pengetahuan keluarga/suami tentang kelas ibuhamil masih kurang. Melalui observasi terhadap kegiatan kelas ibu hamil, keluarga/suami tidak hadir I mendampingi ibu dalam kegiatan kelas ibu hamil tersebut. Juga dipertegas oleh tenaga kesehatan yang menyatakan bahwa dukungan keluarga sangat kurang,keluarga atau suami enggan hadir dalam kegiatan kelas ibu hamil karena berbagai alasan diantaranya karena kesibukan (pekerjaan).

Hasil penelitian inisejalan dengan hasil penelitian yang dilakukan Masini (2015) bahwa dukungan keluarga/suami berhubungan dengan partisipasi ibu hamil dalam kelas ibu hamil, artinya dukungan keluarga/suami menjadi faktor penting bagi ibu untuk mengikuti kelas ibu hamil. Menurut teori Snehandu B Karr, orang cenderung memerlukan dukungan dari masyarakat sekitar (social support) untuk berperilaku, demikian juga dalam berperilaku kesehatan (Notoatmodjo, 2010). Dalam hal ini dukungan keluarga /suami merupakan faktor pendukung ibu dalam mengikuti kelas ibu hamil. Keluarga/suami diharapkan minimal 1 kali pertemuan (Kemenkes RI, 2013). Keterlibatan keluarga/suami dalam mengikuti kegiatan kelas ibu hamil menjadi bentuk dukungan yang penting bagi ibu untuk keikutsertaannya di pertemuan kelas ibu hamil.

Berdasarkan hasil penelitian dan teori diatas, peneliti menganalisa bahwa ibu tidak aktif dalam mengikuti kelas ibu hamil selain dikarenakan karena pekerjaan ibu dirumah, pekerjaan suami juga tidak ada keluarga/suami yang mengantar ibu ke pertemuan kelas ibu hamil. Bagi istri, seorang suami sangatlah penting sebagai panutan dalam mengambil sebuah keputusan sehingga istri selalu menunggu pendapat suami untuk bertindak. 
Ketidakhadiran keluarga/suami dalam kelas ibuhamil selain karena memang pengetahuannya masih kurang juga disebabkan karena faktor pekerjaan/kesibukan suami. Maka menurut peneliti, partisipasi ibu dalam kelas ibu hamil sangat ditentukan oleh dukungan keluarga/suami dalam bentuk kehadiran keluarga/suami didalam kelas ibu hamil

\section{Kecenderungan Dukungan Tenaga Kesehatan terhadap Kelas IbuHamil}

Berdasarkan hasil wawancara mendalam yang dilakukan terhadap informan serta melalui observasi, diketahui bahwa tenaga kesehatan di wilayah kerja telah memberikan dukungan kepada masyarakat khususnya kepada ibu hamil dan keluarga dalam mengkuti kegiatan kelas ibu hamil dengan menyampaikan informasi melalui penyuluhan yang dilakukan di Posyandu, Puskesmas Keliling, dengan memberikan undangan, melakukan kerjasama dengan kelurahan, kader dan tokoh masyarakat. Informan utama dan informan pendukung juga membenarkan bahwa tenaga kesehatan telah melakukan kunjungan rumah ke rumah ibu- ibu hamil dan langsung menginformasikan adanya kegiatan kelas ibu hamil. Namun dalam kelas ibu hamil di wilayah kerja Puskesmas Sungai Salak ini ibu hamil masih tidak aktif mengikuti kelas hamil.

Hasil penelitian ini membantah hasil penelitian yang dilakukan oleh Yuliantika (2016) yang menyatakan bahwa dukungan tenaga kesehatan/Bidan sangat mempengaruhi keikutsertaan ibu hamil dalam mengikuti kelas ibu hamil. Menurut Notoatmodjo (2012) seseorang dalam bertindak seseorang sangat dipengaruhi oleh sikap dan perilaku orangorang yang dianggapnya penting seperti tokoh masyarakat, tokoh agama dan petugas kesehatan. Dalam konteks kelas ibu hamil, bentuk dukungan tenaga kesehatan salah satunya adalah memberikan informasi dan motivasi kepada ibu hamil dan keluarga untuk mengikuti kelas ibuhamil.

Berdasarkan hasil penelitian dan teori diatas, peneliti menganalisa bahwa kecenderungan dukungan tenaga kesehatan terhadap kegiatan kelas ibu hamil diwilayah kerja Puskesmas Sungai Salak ini telah diberikan dengan baik, hal ini dibuktikan dengan adanya himbauan/ajakan dari tenaga kesehatan yang dilakukan melalui kunjugan rumah, undangan, penyuluhan di Posyandu, Puskesmas Keliling, kader juga tokoh masyarakat.Namun dukungan tenaga kesehatan inijuga tidak menentukanperan serta ibu hamil dalam kelas ibu hamil.

\section{KESIMPULAN}

Berdasarkan hasil penelitian yang telah dilakukan, maka dapat diambil beberapa kesimpulan sebagai adalah pengetahuan ibuhamil di wilayah kerja Puskesmas Sungai Salak tentang kelas ibuhamil masihkurang; Sikap ibu hamil terhadap kelas ibu hamilsudah baik (positif) namun tidak menentukan ibu akan berpartisipasi secara aktif dalam kelas ibu hamil; Dukungan Keluarga/suami terhadap kelas ibu hamil di wilayah kerja Puskesmas Sungai Salak ini hanya sebatas saran namun belum dalam bentuk tindakan, maka disini diperlukan dukungan nyata dalam bentuk kehadiran keluarga/suami didalam kegiatan kelas ibu hamil. Karena itu dukungan keluarga/suami sangat menentukan ibu hamil untuk meningkatkan partisipasi ibu dalam kelas ibu hamil; Tenaga kesehatan Puskesmas Sungai Salak dan jajarannya telah memberikan dukungan yang baik terhadap terlaksananya program kelas ibu hamil dengan melakukan advokasi kepada pihak kelurahan/desa juga dengan memberikan informasi kepada masyarakat tentang kelas ibu hamil, namun dukungan inipun tidak begitu berpengaruh terhadap kehadiran ibuhamil dalam kelas ibu hamil.

\section{SARAN}

\section{Bagi Puskesmas Sungai Salak}

Meningkatkan promosi kesehatan tentang kelas ibu hamil tidak hanya kepada ibu-ibu hamil tetapi juga kepada keluarga khususnya suami ibu hamil. Pengetahuan yang kurang dari suami tentang tujuan dan manfaat kelas ibu hamil, sehingga timbul kesadaran dari keluarga / suami memberikan dukungan dalam praktiknya. Karena faktor keluarga/suami sangat mempengaruhi ibu dalam mengambil 
keputusan untuk berperilaku kesehatan seperti mengikuti kelas ibu hamil ini.

Meningkatkan advokasi kepada pihak pengambil kebijakan di kecamatan, kelurahan/desa dalam upaya menyampaikan tentang pentingnya kelas ibuhamil, agar masyarakat dapat memahami dengan baik dan mengaplikasikannya. Terutama untuk

meningkatkan pengetahuan keluarga/suami dalam kelas ibu hamil agar keluarga memahami mannfaat dan tujuan kelas ibu hamil sehingga timbul dukungan suami terhadap kelas ibu hamil ini.

\section{Bagi Tenaga Kesehatan/Bidan didesa}

Meningkatkan upaya penyampaian informasi tentang kelas ibu hamil tidak hanya melalui penyuluhan, tetapi dapat menggunakan mediainformasi melalui leaflet, brosur, poster, pemasangan spanduk dan lain- lain agar pesan dapat diterima masyarakat dengan lebih baik.

\section{Bagi Peneliti selanjutnya}

Hasil penelitian ini mungkin dapat dijadikan referensi untuk menggali lebih dalam lagi tentang penyebab lainnya masalah rendahnya partisipasi ibu hamil dalam mengikuti kelas ibu hamil.

\section{DAFTAR PUSTAKA}

Achmadi U. (2013), Kesehatan Masyarakat, Teori dan Aplikasi, Jakarta : Raja GravindoPerkasa

Baroroh I, Jannah M \& Meikawati, (2017), Hubungan Pengetahuan Ibu Hamil Dengan Keikutsertaan Kelas Ibu Hamil di Wilayah Kerja Puskesmas Jenggot Kota Pekalongan. Jurnal siklus vol. 6 no 2 Juni2017.

Constance Sinlair. (2009). Buku Saku Kebidanan. Jakarta : Buku Kedokteran EGC

17,24,25.Rerievedfromhttp://www.pusat2

Kementerian Kesehatan Republik Indonesia. (2017). Profil Kesehatan Indonesia 2016.Jakarta: Kementerian KesehatanRI .litbang.depkes.go.id/pusat2_v1/wpconte nt/uploads/2015/12/SDGs- DitjenBGKIA.pdf

Kamus Besar Bahasa Indonesia (2014). Pendidikan menurut KBBI (Online) (https://dinikomalasari.wordpress.com/20 14/04/07/defenisi-tingkat-pendidikan/)

Diakses tanggal 30 Agustus2018

Kamus Besar Bahasa Indonesia(2015). Pengertian Ibu Hamil menurut KBBI (online)http://kabardunia.com/health/172 0-pengertian-ibu-hamil-html. Diakses tanggal 23 Agustus2018

Kementerian Kesehatan RI. (2013). Pedoman Pelaksanaan Kelas lbu Hamil. Jakarta :Kementerian Kesehatan RI.

Kementerian Kesehatan RI (2015) Kesehatan Dalam Kerangka Sustainable Development Goals (SDGs). Rakorkop KementerianKesehatan RI , Jakarta 1 Desember 2015

Dinas Kesehatan Indragiri Hilir. (2017). Laporan Kesga Inhil 2017.

Dinas Kesehatan Provinsi Riau.(2017). Profil Kesehatan Provinsi Riau 2016

Dirjen Bina Gizi KiA, K. R. (2015). Kesehatan dalam Kerangka Sustainable Development Goals (SDGs). Rakorpop Kementerian Kesehatan Rl, (97).

Kementerian Kesehatan Republik Indonesia. (2016a). Profil Kesehatan Indonesia 2015 Jakarta : Kementerian Kessehatan $\mathrm{RI}$

Kementerian Kesehatan Republik Indonesia (2016b). Laporan Tahunan Direktorat Kesehatan Keluarga :Jakarta: Kementerian Kesehatan RI

KumparanSAINS (2017). Angka Kematian Ibu dan Bayi Indonesia Tertinggi Kedua di Asia

Tenggara.https://kumparan.com/@kum 
paransains/angka-kematian-ibu- danbayi-indonesia-tertinggi- kedua-di-asiatenggara, 28 Maret 2018. Diakses tanggal 10 September2018

Martha E \& Kresno (2016). Metodologi Penelitian

Kualitatif Untuk Bidang Kesehatan. Jakarta : PT. RajagrafindoPersada

Masini.(2015). Pengaruh Gravida, Pekerjaaan, Dukungan Suami, Dukungan Bidan/Tenaga Kesehatan Terhadap Partisipasi Kelas Ibu Hamil di Kabupaten Magelang.Jurnal Kebidanan Vol 4 Nomor 8 April2015

Notoatmodjo, S. (2010), Promosi Kesehatan, Teori dan Aplikasi. Jakarta : Rineka Cipta

Notoatmodjo,S.(2012), Promosi Kesehatan dan IImu Perilaku.Jakarta : Rineka Cipta

Pusat Data dan Informasi Kementerian Kesehatan RI. (2014). Mother's Day Puskesmas Sungai Salak.
(2017). Laporan PWS KIA tahun 2017.

Ranny Septiani.(2013). Pengetahuan, Sikap Ibu Hamil dan Dukungan Suami dengan Keikutsertaan Ibu Hamil dalam Kelas Ibu Hamil di Puskesmas Kota Metro Lampung. Skripsi: Poltekkes Kemenkes Tanjung Karang Jurusan Kebidanan

Reni Faradevi. (2011). Perbedaan Besar Pengeluaran Keluarga,Jumlah Anak Serta Asupan Energi dan Protein Balita Antara Balita Kurus dan Normal, Skripsi: Universitas Diponegoro Fakultas Kedokteran Program Studi IImuGizi

Yuliantika.(2016). Faktor yang berhubungan dengan Partisipasi lbu Hamil Risiko Tinggi Dalam Mengikuti Kelas Ibu Hamil di Wilayah Kerja Puskesmas Sukolilo 2.Skripsi.Universitas Negeri Semarang, Fakultas IImu Keolahragaan Jurusan IImu KesehatanMasyarakat 